セキ法では, レモン色に着色したが，皮膜には，硫

化カドミウムの存在するのを認めた。

なお，末尾ではあるが，この研究を遂行するに際し

て, 種々, 御指導をいただいた, 浅田太平博士に厚く御 礼を申し上げる。

(1969-1-29 受理)

(昭和43年 5 月, 本協会第37回学術講演大会および昭和 43年11月, 本協会第38回学術講演大会にて発表)

\section{文献}

1) 宮田, 鰕原, 電気化学, 3, 60 (1935)

2) 森田, 日本特吘, 245502
3 ) 浅田, 日本特新, 310401

4) C. Giles, H. Mehta, S. Rahman \& C. Stewart, J. Appl. Chem., 9, 457 (1959)

5) 上田, 木村, 粒子線回折, p. 12 (1950, 朝倉書店)

6) J. Edwards \& F. Keller, Trans. Electrochem. Soc., 79, 135 (1941)

7) F. Keller, M. S. Hunter \& D. L. Robinson, J. Electrochem. Soc., 100, 411 (1953)

8 ) 浅田, アルミニウム表面処理研究調查報告, 本誌 16, 1, (1967)

\title{
無電解ニッケルーホウ素メッキ皮膜の 熱処理による相変化
}

\section{神 戸 徳 蔵*}

\section{Phase Changes in Electroless Ni-B Deposits during Heat Treatment}

Tokuzo KANBE*

The phase changes in electroless $\mathrm{Ni}-\mathrm{B}$ deposits during heat treatment are reported in this paper.

The experiments were conducted by thermal and X-ray analyses in nearly the same method as in the previous reports.

The results obtained were as follows:

1) The hardness after heat treatment of electroless $\mathrm{Ni}-\mathrm{B}$ deposits exhibited its maximum at about $400^{\circ} \mathrm{C}$ as shown in the curves.

2) Exothermic change was observed at about $270^{\circ} \mathrm{C}$ in the curves plotted by thermal analysis of electroless $\mathrm{Ni}-\mathrm{B}$ deposits.

3) It was possible to comfirm the formation of nickel boride at the temperature of exothermic change, judging from the $\mathrm{X}$-ray diffraction pattern of electroless $\mathrm{Ni}-\mathrm{B}$ deposits.

\section{1. 緒害}

無電解ニッケルメッキにおいて, 還元剤に次覀リン酸 ナトリウムを使用する研究はすでに数多く報告されてお り、メッキ皮膜中に含まれるリンが $300^{\circ} \mathrm{C}$ 以上の温度で 化合物を形成し，それが硬化に寄与すると考えられてい $3^{1), 2), 3) 。}$

今回は近年発表4)された還元剤に水素化ホウ素ナトリ ウムを使用するアルカリ性無電解ニッケルメッキについ て, 浴温と析出量の関係, 熱処理後の無電解析出皮膜の

†無電解二ッヶルーホウ素メッキ皮膜の性状について (第 1 報)

* 産業工業試験所（東京都大田区下丸子） Industrial Arts Institute
カタサ変化, $\mathrm{X}$ 線回折による熱処理後の構造変化, 示差 熱分析による熱的変化などについて検討した結果を報告 する。

\section{2. 試料および実験方法}

無電解ニッケルーホウ素メッキ皮膜の析出には, 第 1 表に示す浴組成のニボダー浴4を用いた。

浴の調慗は純水 $600 \mathrm{cc}$ に塩化ニッケル, エチレンシ アミン, 水酸化ナトリウム, フッ化ナトリウム, 水素化 ホウ素ナトリウム, 塩化鉛を順次溶解させ, 最後に純水 を加えて全量を 1 lとした。

上記の調製浴を用い，浴量 $500 \mathrm{cc}$ 一定のもとに怙け る浴温と析出量の関係を，浴を更新した場合およびしな 
い場合について実験した。

まず浴を更新しない場合は, $50,60,70,80,90^{\circ} \mathrm{C}$ 亿 保った浴中に $30 \mathrm{~cm}^{2}$ のスチールハク（厚サ約 $35 \mu$ )を 9 枚浸セキし, 所定時間 $(0.5,1,2 \mathrm{~h})$ 経過後とり出 して重量測定を行ない, 浸セキ前後の重量差の平均から 析出量を求めた。

浴更新のものについての浴量は前記同様で, 新液流入 量を $0.5 \mathrm{l} / \mathrm{h}$ とし，スチールハク $30 \mathrm{~cm}^{2}$ のものを 9 枚 浸七キして, 所定時間 $(0.5,1,2 \mathrm{~h})$ 経過後その内の 3 枚ずつをとり出し重量の測定を行ない, 浸セキ前後の 重量差の平均から析出量を求めた。

つぎにカタサ測定に用いた試料は, 素地の影響をさけ るため $90^{\circ} \mathrm{C}$ の浴温中で軟鋼板上に厚サ $10 \mu$ 以上の皮 膜を析出させたのち, 真空中 $\left(10^{-2} \mathrm{mmHg}\right)$ および水 素気流中 (流量 $1 \mathrm{l} / \mathrm{min}$ ) に拀いて, それぞれ所定の温 度に処理したもので, このときの加熱冷却速度は $200^{\circ} \mathrm{C} /$ h とした。また，カ夕サ測定は荷重 $100 \mathrm{~g}$ で行なった。

無電解析出皮膜の組成の検討には, スチールハクを試 料とし, 浴温 $90^{\circ} \mathrm{C}$ に扔いて $1 \mathrm{~h}$ 浸七キ処理したものを 用い, ジクロルエタン抽出光度法でホウ素量を分析した のち，その残分をニッケル量とした。

熱処理後の構造解析については, カタサ測定と同一試 料を用い, X線回折法により無電解析出時および熱処理 後の回折線の変化から求めた。

示差熱分析の試料には, 銅板上に浴温 $90^{\circ} \mathrm{C}$ で無電解 析出させた皮膜を $10 \%$ クロム酸と $10 \%$ 硫酸を含む水溶液 に浸セキし,銅板のみを溶解させたのち,その析出物を取 り出してー100メッシュ程度の粉末状としたものを $0.6 \mathrm{~g}$ 採取して試料とした。また, 測定の際の中性体には $\alpha$ 一 $\mathrm{Al}_{2} \mathrm{O}_{3}$ を使用し, 真空中 $\left(10^{-2} \mathrm{mmHg}\right)$ で $5^{\circ} \mathrm{C} / \mathrm{min}$ に 升温させながら起電力の変化を示差熱テンビンにより測 定した。

\section{3. 実 験 結 果}

\section{3-1 浴温と析出量の関係}

浴を更新しない（浴を補充しない）場合, 浴温の変化 に伴ら浸七キ時間と析出量の関係を第 1 図に示す。

第1表 浴 組 成

\begin{tabular}{lr}
\hline \hline $\mathrm{NiCl}_{2} ・ 6 \mathrm{H}_{2} \mathrm{O}$ & $30 \mathrm{~g}$ \\
$\mathrm{NaOH}$ & $40 \prime \prime$ \\
エチレンシアミン(Sp. gr. 0.9) & $60 \prime \prime$ \\
$\mathrm{NaF}$ & $3 \prime \prime$ \\
$\mathrm{NaBH}_{4}$ & $0.5 \prime \prime$ \\
$\mathrm{PbCl}_{2} ・ \mathrm{aq}(2 \mathrm{~g} / l)$ & $30 \mathrm{cc}$ \\
全 量 & $1,000 \prime \prime$ \\
\hline
\end{tabular}

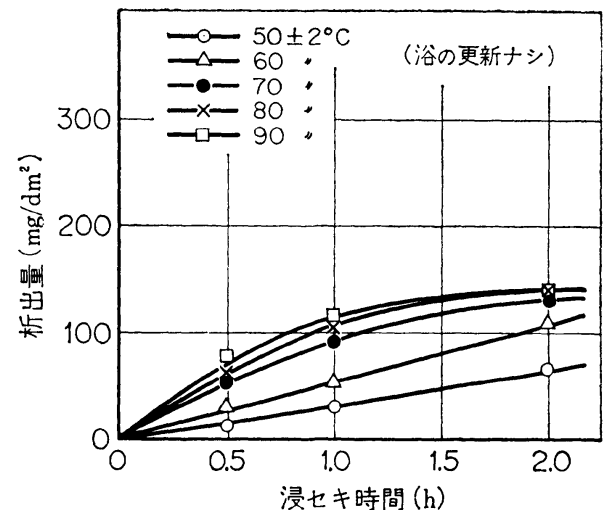

第 1 図 浴温の相違による析出量の経庤变化

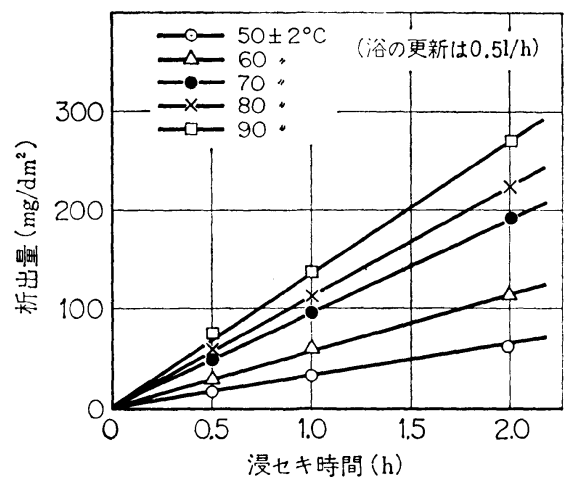

第 2 図 浴温の相違による析出量の経時変化

すなわち, 無電解析出量は浸セキ時間, $1 \mathrm{~h}$ 以内に括 いて浴温の上年に比例して增加しているが，1 $\mathrm{h}$ 以上に なると $80,90^{\circ} \mathrm{C}$ 場合, 水素化ホウ素ナトリウムの還元 能力が低下して, 単位時間当りの析出量の增加割合に減 少傾向が認められた。この現象は浴温が高くなるにした がい, 水素化ホウ素ナトリウムそれ自体の分解反応が急 激に起こり，ニッケルイオンを還元析出する浴の能力が 低下したものと考觉らる。

上記の実験結果から, 水素化ホウ素ナトリウムそれ自 体の分解を考慮して, 浴中のニッケルイオンを還元析出 させる能力を低下させないようにするには, 浴の更新速 度を $0.5 \mathrm{l} / \mathrm{h}$ に調整するのが適当である。そこでこの 条件を考虑した場合の実験を行なった。

第 2 表 浴温とホウ素含有量の関係

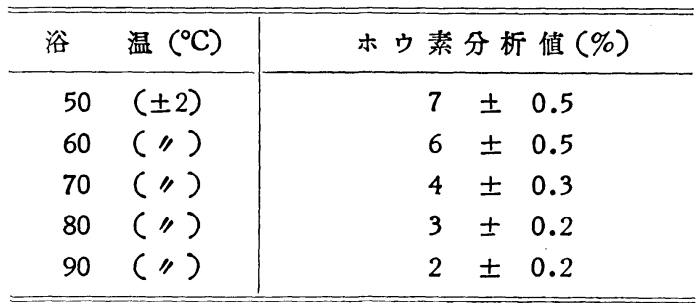




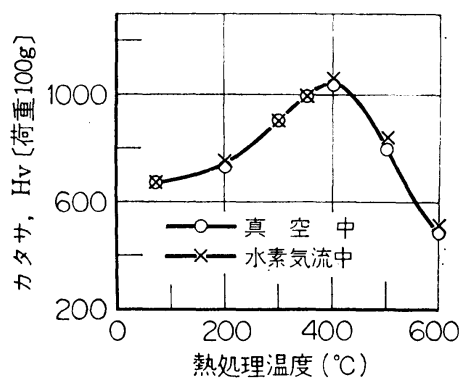

第3図熱処理温度とカタサの関係

第 2 図はこの結果を示したものでいずれの場合も浴温 の高いものは, 低いるのに比較して析出量が多く, ま た，浸セキ時間と析出量の間には一次関数的な関係が成 立することを認めた。

つぎに各種浴温にて，1 $\mathrm{h}$ 浸セキ処理した試料のホウ 素含有量の分析值を第 2 表に示す。

この結果に怙いて，分析值にかなりのバラッキを生じ たのは浴温の誤差による影響と思われる。したがって, 浴温の誤差範囲を $\pm 2^{\circ} \mathrm{C}$ より少なくすれば, 分析値のバ ラッキを小さくすることが可能であろう。

\section{3-2 熱処理後のカタサ変化}

真空中拈よび水素気流中で熱処理を扣こない，そのと きのメッキ皮膜のカタサ测定結果を第 3 図に示した。

第 3 図上り真空中, 水素気流中ともに $400^{\circ} \mathrm{C}$ 付近に力 タサのピークが認められた。

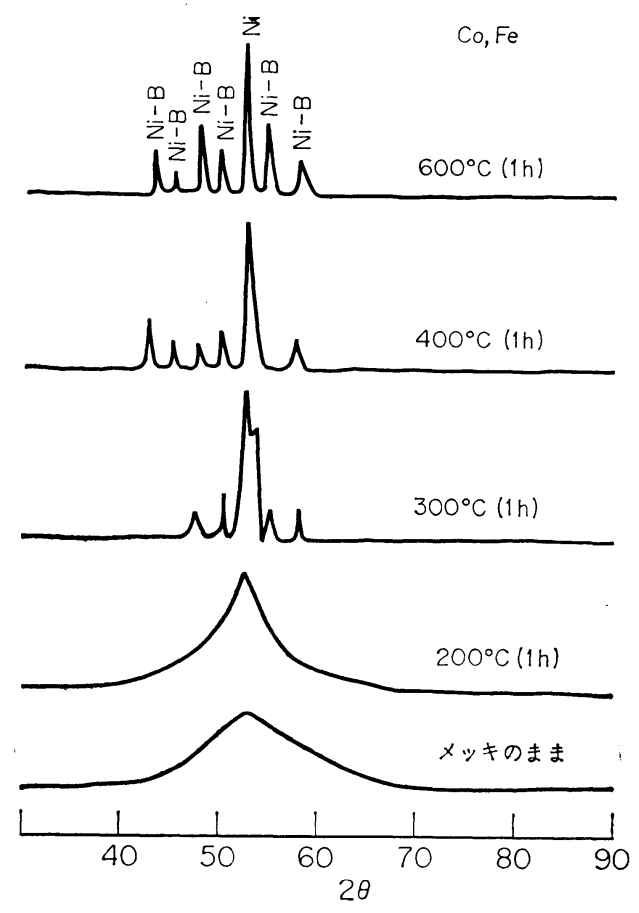

第4図熱処理による構造変化

\section{3-3 熱処理による構造変化}

熱処理温度とカタサの関係に使用した試料をX線回折 により構造解析したのが 第4 図 である。

これによると,メッキのまま（無電解析出時）のるの は, diffuse な回折図形を示すことが認められる。しか し，これを熱処理すると $300^{\circ} \mathrm{C}$ 付近までは $\mathrm{Ni}(111)$ に 相当する回折線の成長がみられ，より高温側飞おいて $\mathrm{Ni}$ 線以外にニッケルーホウ素の.化合物と思われる回折 線が見出されるようになり，この傾向は熱処理温度が高 くなるほど鮮明となることが認められた。

\section{3-4 熱的性質}

無電解析出皮膜の加熱時の熱的性質を示差熱分析法に より測定した。

第5図はこの結果を現わしたものでメッキ皮膜は $270^{\circ} \mathrm{C}$ 付近から急激に発熱を起こすことが確認された。

以上の熱的変化々第 4 図 のX線回折図形々を比較検 討すると，ニッケルーホウ素化合物の析出が認められた 熱処理温度と一致している。

な拈, $410^{\circ} \mathrm{C}$ 付近に拈ける発熱については, 現在検討 中である。

\section{4. 考 察}

無電解ニッケルーホウ素メッキ皮膜は熱処理を施すこ とにより， $400^{\circ} \mathrm{C}$ 付近にピークを持つカタサ変化を示す ことが認められた。

この硬化は 第 4 図 のX線回折図形からニッケルーホ ウ素化合物の生成に起因すると思れる。そこで, ニッケ

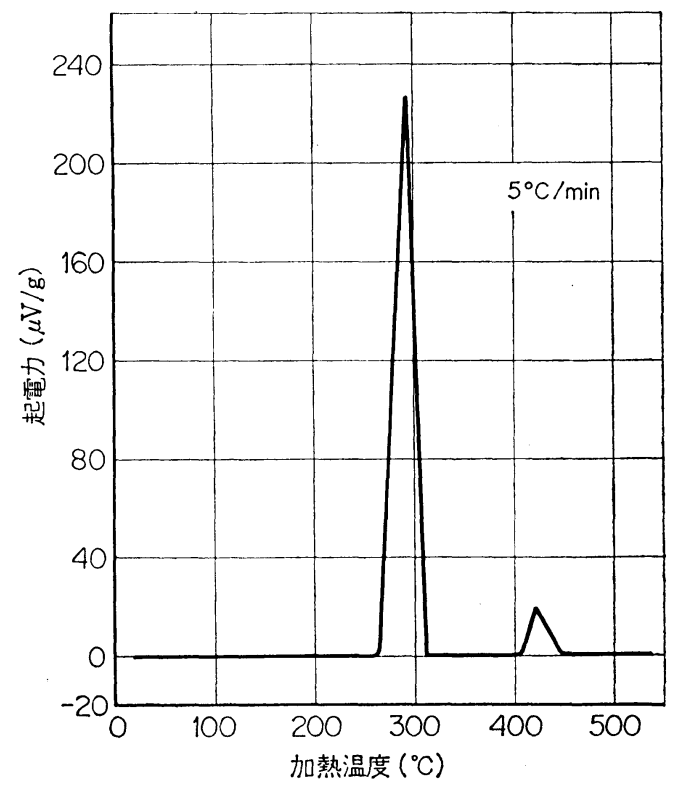

第 5 図 無電解ニッケルーホウ素メッキ皮膜の 示差熱分析 


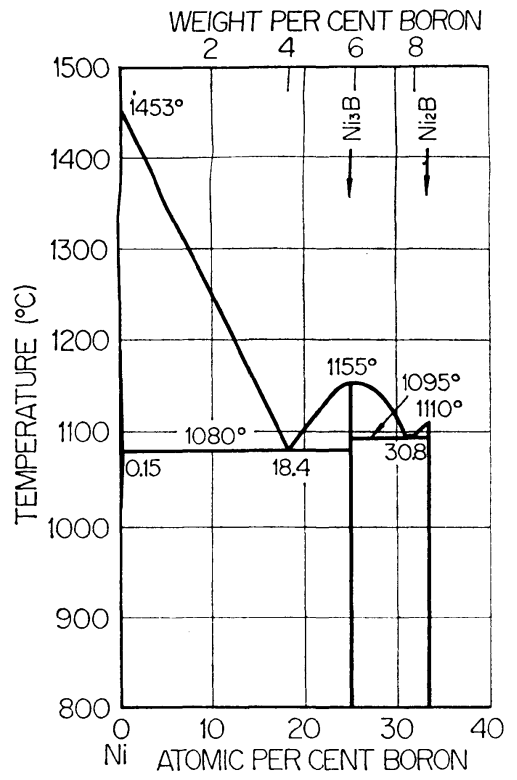

第 6 図 ニッケルーホゥ素状態図

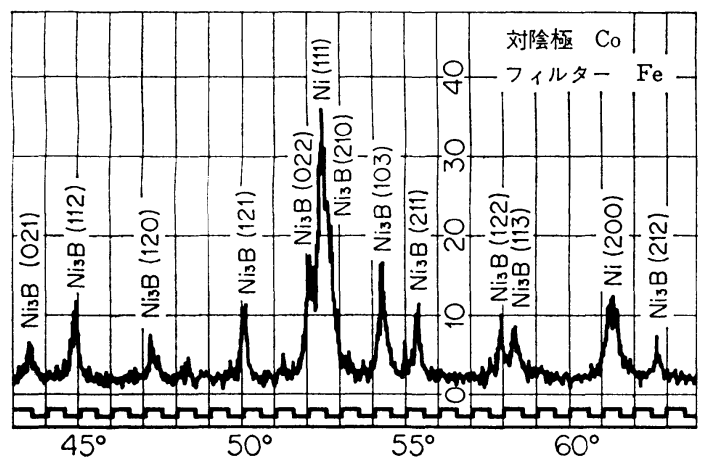

$2 \theta$

第 7 図 Ni, B 混合粉末圧粉体の焼結後の X線 回折図形

ル一ホウ素化合物として予想される $\mathrm{Ni}_{3} \mathrm{~B}$ について考察 を試みた。

金相学的には Ni-B系は 第 6 図 に示すように固溶度 は非常に小さく，ホウ素 $6 \mathrm{Wt} \%$ 以下では $\mathrm{Ni}_{3} \mathrm{~B}$ といら 化合物が認められている5)。

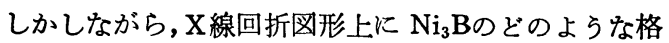
子面が強く現われるかについての文献が見当らず，検討 方法として， $\mathrm{Ni}_{3} \mathrm{~B}$ と非常によく似た構造を持つ $\mathrm{Co}_{3} \mathrm{~B}$ のデータ6)をるとに, $\mathrm{Ni}_{3} \mathrm{~B}$ の回折線が強く現われるで あ万万格子面の面間隔 (d)を第 3 表に示す方法にて 求め, これを $\mathrm{Ni}_{3} \mathrm{~B}$ calculate として表中に示した。

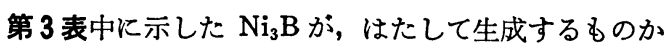
否かを検討するため, 粉末ヤ金法によりニッケルとホウ 素を $\mathrm{Ni}_{3} \mathrm{~B}$ 組成割合に混合して $5 \mathrm{t} / \mathrm{cm}^{2}$ のもとで压粉
第3 表 $\mathrm{Co}_{3} \mathrm{~B}$ と $\mathrm{Ni}_{3} \mathrm{~B}$ 構造

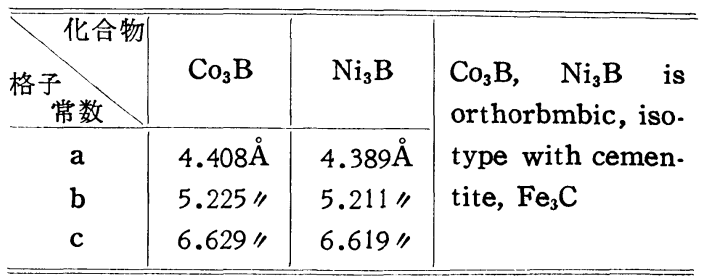

orthorbmbic

$$
\frac{1}{\mathrm{~d}^{2}}=\frac{\mathrm{h}^{2}}{\mathrm{a}^{2}}+\frac{\mathrm{k}^{2}}{\mathrm{~b}^{2}}+\frac{l^{2}}{\mathrm{c}^{2}}
$$

\begin{tabular}{l|r|c|c}
\hline \multicolumn{3}{|c|}{$\mathrm{Co}_{3} \mathrm{~B}$} & $\mathrm{Ni}_{3} \mathrm{~B}$ calculate \\
\hline $\mathrm{dA}$ & $\mathrm{I} / \mathrm{I}_{1}$ & $\mathrm{hk} l$ & $\mathrm{~d} \AA$ \\
\hline 2.430 & 20 & 021 & 2.425 \\
2.363 & 40 & 112 & 2.357 \\
2.247 & 20 & 120 & 2.241 \\
2.128 & 50 & 121 & 2.122 \\
2.051 & 70 & 022 & 2.047 \\
2.031 & 70 & 210 & 2.023 \\
1.975 & 100 & 103 & 1.971 \\
1.942 & 70 & 211 & 1.934 \\
1.860 & 60 & 122 & 1.855 \\
1.848 & 50 & 113 & 1.844 \\
1.732 & 60 & 212 & 1.726 \\
1.687 & 30 & 023 & 1.684 \\
1.657 & 20 & 004 & 1.655 \\
1.620 & 70 & 130 & 1.615 \\
\hline \hline
\end{tabular}

第 4 表 $\mathrm{Ni}_{3} \mathrm{~B}$ の実测值と計算值との関係

\begin{tabular}{c|c|c}
\hline $\mathrm{hk} l$ & $\mathrm{Ni}_{3} \mathrm{~B}$ calculate & $\mathrm{Ni}_{3} \mathrm{~B}$ observe \\
\hline 021 & $2.425 \AA$ & $2.424 \AA$ \\
112 & 2.357 & 2.357 \\
120 & 2.241 & 2.239 \\
121 & 2.122 & 2.124 \\
022 & 2.047 & 2.048 \\
210 & 2.023 & 2.022 \\
103 & 1.971 & 1.970 \\
211 & 1.934 & 1.934 \\
122 & 1.855 & 1.857 \\
113 & 1.844 & 1.842 \\
212 & 1.726 & 1.724 \\
023 & 1.684 & - \\
004 & 1.655 & - \\
130 & 1.615 & 1.616 \\
\hline \hline
\end{tabular}

体を作成し, 水素気流中に㨟いて, $850^{\circ} \mathrm{C}-50 \mathrm{~h}$ 焼結し た。第 7 図はこのX線回折図形を示したものであり, 
第 5 表 $600^{\circ} \mathrm{C}(1 \mathrm{~h})$ 熱処理後のニッケルーホウ 素メッキ皮膜中に現われた $\mathrm{Ni}_{3} \mathrm{~B}$ の格子面

\begin{tabular}{c|c|c}
\hline \hline $\mathrm{hkl}$ & $\mathrm{Ni}_{3} \mathrm{~B}$ calculate & $\mathrm{Ni}_{3} \mathrm{~B}$ observe \\
\hline 021 & $2.425 \AA$ & $2.424 \AA$ \\
112 & 2.357 & 2.357 \\
120 & 2.241 & 2.243 \\
121 & 2.122 & 2.124 \\
022 & 2.047 & 2.048 \\
210 & 2.023 & 2.022 \\
103 & 1.971 & 1.970 \\
211 & 1.934 & 1.934 \\
122 & 1.855 & 1.854 \\
113 & 1.844 & 1.845 \\
212 & 1.726 & 1.727 \\
023 & 1.684 & 1.683 \\
004 & 1.655 & - \\
130 & 1.615 & 1.616 \\
\hline \hline
\end{tabular}

焼結条件は上記の熱処理に伴らカタサ変化を求めた実験 と同じである。

第 7図 より $\mathrm{Ni}_{3} \mathrm{~B}$ と思われる格子面は図中に示した通 りである。この $\mathrm{Ni}_{3} \mathrm{~B}$ の実测值 (observe) と第 3 表に 示した $\mathrm{Ni}_{3} \mathrm{~B}$ の calculate を比較すると第 4 表に示す ようになる。

第 4 表から calculate $と$ observe は小数点以下 3 ケ タ目が多少異なる程度でほとんど一致していることを認 めた。したがって, $\mathrm{Ni}_{3} \mathrm{~B}$ についても $\mathrm{Co}_{3} \mathrm{~B}$ と同様な格 子面が強い回折を示すものと判断される。

つぎに無電解ニッケル一ホウ素メッキ皮膜について粉 末ヤ金法のニッケル一ホウ素と同様な方法で比較した結 果を第 5 表に示す。
この結果から $\mathrm{Ni}_{3} \mathrm{~B}$ の calculate と observe がそれ ぞれの格子面について良く一致することが認められた。

以上の結果に基づき, 無電解ニッケル一ホウ素メッキ 皮膜は $300^{\circ} \mathrm{C}$ 以上の温度で熱処理することにより $\mathrm{Ni}_{3} \mathrm{~B}$ を形成するものと思われる。また，熱処理温度 $400^{\circ} \mathrm{C}$ 以 上に拈ける軟化については, $\mathrm{Ni}$ および $\mathrm{Ni}_{3} \mathrm{~B}$ 結晶粒子 の成長と内部ヒズミの軽減など基づくものと考える。

\section{5. 結言}

無電解ニッケルメッキに還元羭として水素化ホウ素ナ トリウムを使用すると，メッキ皮膜中にニッケル以外に ホウ素が含まれる。この皮膜を熱処理すると $400^{\circ} \mathrm{C}$ 付近 にカタサのピークが現われることが認められた。

また，このメッキ皮膜は $270^{\circ} \mathrm{C}$ 付近から急激な発熱を 伴って, $\mathrm{Ni}_{3} \mathrm{~B}$ を形成することが認められる。

最後にこの研究に協力していただいた，新潟県工業技 術センターの菊池考之氏に深く感謝します。

(1969-2-4 受理)

(昭和43年11月本協会第38回学術講演大会にて発表) 文献

1) A.W. Goldenstein, W. Rostoker \& F. Shossberger, J. Elec. chem., 104, 104 (1957)

2) A. H. Graham, R. W. Lindsay \& H. J. Reed, J. Elec, chem., 112, 401 (1965)

3 ) 三谷, 庄司, 神戸，本誌，17，379 (1966)

4) K. Lang, Elec. plating \& Metal finishing, 3, 86 (1966)

5) R. P. Elliot, Constitution of Binary alloys, p. 127 (1965)

6) R. Fruchart and A. Michel, Bull. Soc. chem., France, p. 422 (1959)

\section{<研 究>}

\section{次量予告}

シンケート浴からの光沢亜鉛メッキ(第 3 報) 小西 三郎 (阪 府工奖)

プラスチック上の電気メッキのエッチング機構に関する一考察. 本 間 英 夫 (関東学院大)

アミノ酸錯塩浴よりの銅メッキ 乾 (他 2 名) 孝 (九州工大)

ゲルマニウムーインジウム合金形 $\mathrm{P}-\mathrm{N}$ 接合素子の アルカリ性電解および酸性化学エッチング……..........川 田 淳一郎 (富 士 通) 無電解コバルトーニッケルおよびコバルトーニッケルーリソ 合金メッキ皮膜の磁気特性.

鷹 (野 1 名) 修(姫路工大)

低マンガン溶着鋼の乾燥・すべり摩耗特性について

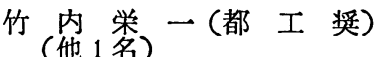

